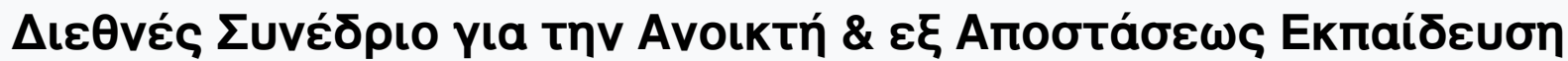

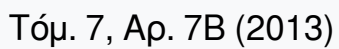

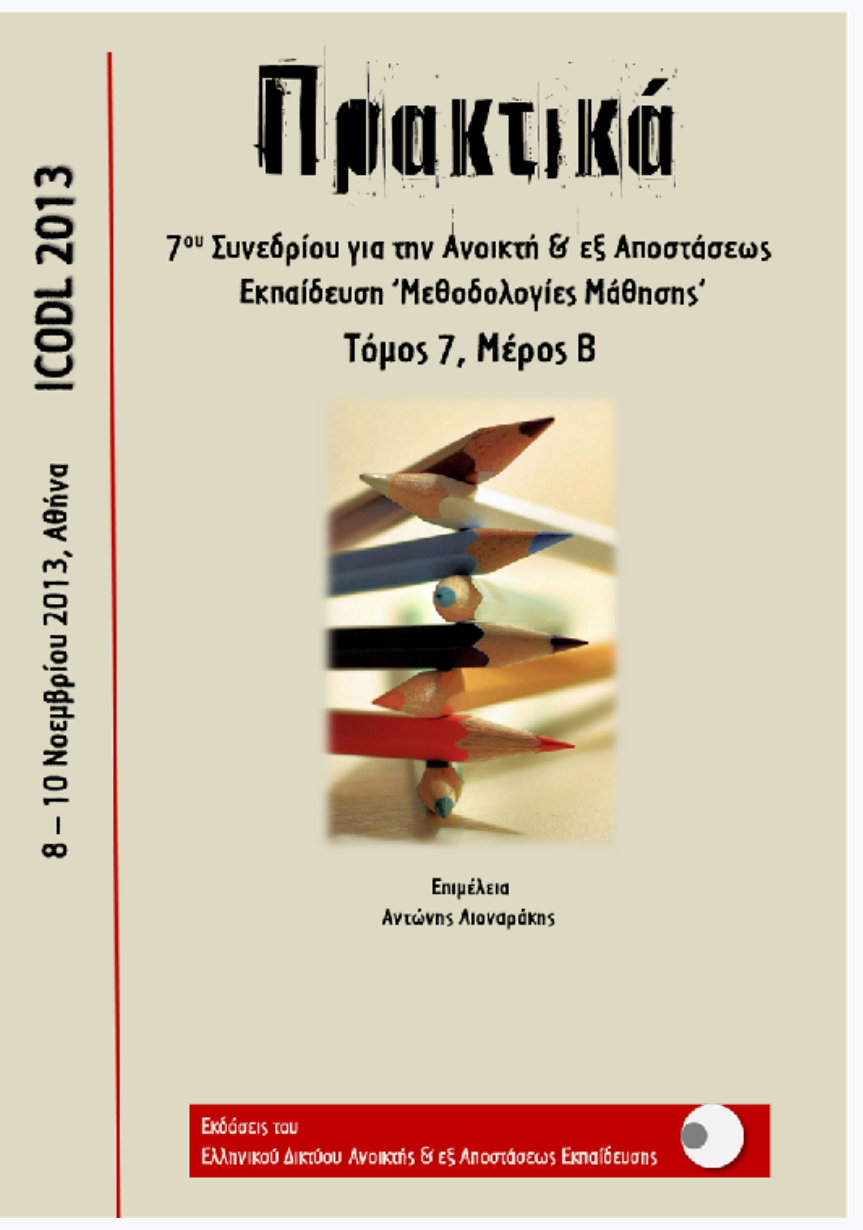

Approaching Art in distance learning: The necessity of oral interaction

Nikolaos Trivyzadakis

doi: $10.12681 /$ icodl. 636 


\title{
Approaching Art in distance learning: The necessity of oral interaction
}

\author{
Nikolaos Trivyzadakis \\ Greek Open University \\ School of Applied Arts \\ Member of the Adjunct Faculty (Tutor) \\ nikolaostrivyzadakis@gmail.com
}

\begin{abstract}
A thorough examination of Art as Phenomenon and scientific field reveals the great connection of it with philosophy since it was the evolution of philosophical thought that formed the theoretical background for the classification and evaluation systems (Fine and Applied Arts) that modern man uses to understand and approach it. The conception of that fact is crucial for the methods that should be preferred for the instruction of artistic and aesthetic courses within the frames of higher education programs since teaching Art should be treated proportionally as teaching Philosophy. As a result, the tuition should be based on dialogue, live interaction and mainly oral communication between tutors and students. Conventional education conducted inside classroom, structurally focuses on the personal contact between everyone involved in the didactical process and thus creates the necessary premises for the tuition of Art and Philosophy. However, distance learning programs should pay a great deal of attention to that matter, since all methods of distance learning are not proper for ensuring the above conditions. We must take under consideration the division of distance education in asynchronous and synchronous, with the latter one using basically sound and video conference, being the appropriate suggestion for the creation of a successful substitute of an educational atmosphere of immediate socialization and opinion's exchange among students and teachers. In that way, Art, regardless Fine or Applied orientation, would be instructed as a scientific course through its aesthetical and philosophical depth, without being downgraded to the level of empirical knowledge.
\end{abstract}

\section{Introduction}

The initial approach of a complete system of higher education, whether it has to do with conventional or distance learning orientations and methods, should pay a great deal of attention in the organization of humanitarian studies disciplines as the last ones consist the theoretical basis and the potential moral background over which the evolution of all sciences (especially the natural sciences) develops and the achievements of their research should aim. In that frame, a major area of humanitarian scientific interest is the field of Art, both in the domain of Fine and Applied Arts.

\section{Art as Philosophy}

The meaning of the word Art in Antiquity was different to what modern man understands. Art was a term with wider context that included all products of human creation, mental or material, which were produced according to specific rules, as well as the processes for their creation (Tatarkiewicz, 1963). Inevitably, Art was an organized knowledge and procedure that developed, evolved and applied for the achievement of the production of a concrete result, which gave material existence to 
notions and concepts of the artist or craftsman. In any case, the final product of Art, which always referred to man and to the amelioration of the quality of his life (Collingwood, 1974), could be a natural object (e.g. sculpture), an activity (e.g. sewing), but also a spiritual or corporal condition relative to man (e.g. medicine, rhetoric) or to animals (e.g. breading animals) (Pollitt, 1974).

That view of Art started to change during the 17th and mainly the 18th century, when the aesthetical thought started to become independent after the meeting of Art with the Philosophy of the Enlightment. Nonetheless, that was not the first time where Art and Philosophy came in contact since there has never been a philosopher who didn't deal with affairs of Art (Danto, 2000). We must always bear in mind that Art is a field of activity that provokes continuously and intensively philosophy to explore it. For example, the ancient philosopher Aristotle divided philosophy in theoretical, practical and poetical, where the third branch is equivalent to what is today understood as

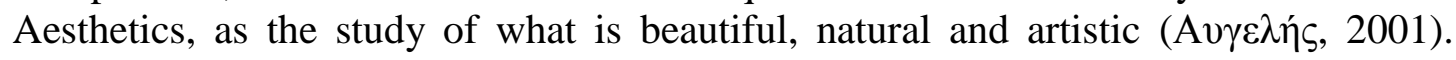
According to Aristotle, with the poetical Art man can give birth to new beings that do not exist in nature in order to complete the work of nature since the new beings not only present that what exists in nature but also they reveal its deeper and inner

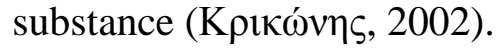

Coming back to the 17th century, Philosophy introduces an innovation about the way man should gaze and evaluate Art. That innovation was the appearance of the term Fine Arts (Beaux Arts) that is used by the philosopher Charles Perrault (1628-1703), who divides Liberal from Fine Arts by defining the last ones as "les Arts qui méritent d'être aimés et cultivés par un honnête homme ceux qui se sont trouvées davantage $d u$ goût et du genie" (Kristeller, 1951, p. 527). After him, another French philosopher, Abbé Batteux (1713-1780) gives special place to poetry, painting, sculpture, music and dance among other human activities, since he considers them different appearances of a common substance, which is the Mimesis of Pretty Nature (la Belle Nature) (Beardsley, 1989). In the same spirit, Jean le Rond D'Alembert (1713-1783) in his work Discours Préliminaire de l'Encyclopédie approaches Fine Arts as a subdivision of Liberal Arts that seek pleasure and are based on the Mimesis of Nature, while the lemma "Art" in the Encyclopédie ou Dictionnaire Raisonné des sciences, des arts et des métiers (1781) denotes clearly that the pleasure that derives from Fine Arts should fulfill the need for moral improvement of society. As a result, a new view of Mimesis as beautification and idealization of Nature is evident, demanding from the artist perpetual observation, spiritual judgment, imagination, intellect and practice (Boas, 1964).

Anyhow, the Philosopher who completed the theoretical structure of Fine Arts is Immanuel Kant (1724-1804), whose aesthetical thought based on the selflessness of aesthetical judgment, posed as main aim of Fine Arts the pursuit of Beauty. The Beauty of Fine Arts is evident for the appreciation of the Beauty of Nature. In this way, Fine Arts that can be nothing but the product of work and creativity of a conscious and free will, are related to basic cognitive functions of human mind and therefore are presented as a cultural and social necessity since they facilitate the procedures of understanding rational and natural processes that can lead to the amelioration of human society (Beardsley, 1989; Kemal, 1986).

As a result of all that philosophical activity, modern thought ended at approaching the substance and the phenomenon of Art through the classification and evaluation system of Fine Arts (Souriau, 1969), the core of which are the five basic Arts: Painting, Sculpture, Architecture, Poetry and Music (Kristeller, 1951). All these Arts are related to activities, practices and habits, which appeared very early in human 
history and characterize it throughout time. The artistic interest for the line, the color, the chiaroscuro, the sculpture, the motion of the body, the voice or the pure sound, consciously and unconsciously is always evident and labels the effort of man to realize with natural means his inner experiences, thoughts and impulses (Munro, 1954).

Having the same ideological and theoretical background, Applied Arts came as a distinctive category of human activity compared to Fine Arts after a "quarrel " among artists and philosophers of two different orientations. The first one was faithful in the isolation of Fine Arts, while its supporters believed that artistic behavior should remain exclusive, inner and in a way aristocratic. On the contrary, the second tendency, which was deeply affected by evolutions and achievements of Political Philosophy, wanted the assimilation of Fine Arts and common crafts, so as the artistic developments should become property of of all people, of all societies (Pov́ $\pi \alpha, 2003$ ). The result of that struggle was finally the ideological strengthening of Applied Arts under the general idea of the "Unity of Art". Applied Arts do not fulfill their destination in the view of themselves, as Fine Arts do, but exploit the background, the methods and the imagination from the field of Fine Arts in order to create solid and concrete forms and objects that claim a practical role in the everyday life of man (Nichols, 1877).

\section{Teaching Art}

The above analysis made clear and obvious that every attempt to analyze academically the phenomenon of Art in order to transmit didactically its ideological and theoretical branches within a higher education program should focus in the philosophical background that is crucial as the substantive essence of everything that is artistic and aesthetic. In our days, Art is characterized by plurality (Danto, 1998). The awareness of that fact is very important since through that plurality even an everyday common object can be upgraded to the level of artistic production regardless its external attributes or appearances under the condition that this object embodies an idea, which is about "something" (Danto, 2001). That "something" is the quest of philosophy, the question that all philosophers seek to answer (Danto, 1974). Inevitably, the question concerning how Art should be instructed, both in conventional and distance-learning institutions, is answered by the following phrase: teaching art means, in one-way or another, teaching philosophy.

To understand the ways of Philosophy, we can use as example an analogy from a myth that is delivered by the Philosopher Plato (428-348 B.C.) in his work named Phaedrus (274c - 277b). According to the myth, an ancient Egyptian god named Theuth made many inventions in sciences, arts and crafts in order to present them to the Egyptian king, Ammon. Among his inventions, he believed that the alphabet or written language was the most important, since it could be the key to make people wiser and stronger in memory. Despite his expectations, Ammon criticized him by saying that the written language will provoke oblivion to the people that will learn and use it, since they will no longer use their memory and mind in a creative way, showing full trust to the written texts. In this way, all students of written speech can acquire nothing but a phenomenological wisdom, without truly knowing anything. The final conclusion that derives from that myth, according to Plato, is that the best way to make people wiser by teaching them good qualities and philosophy is the use of the dialectic art or the dialogue based on oral speech. In this way, an instructor that has the purpose to extract from his students wisdom, virtue and justice must not pay his attention to the written recording of his deeper thoughts, but to the slow and 
steady cultivation of his beliefs and doctrines in the souls of his students through personal contact, oral interaction and constructive dialogue (Taylor, 2003; $\Delta$ óïкоs, 2001).

It became clear that teaching Philosophy and Art is not a steady but a dynamic process that requires dialectic contacts, exchange of opinions and creative controversies not only between the tutor and his students but also among students themselves. The basic mean for that interaction can be nothing else than oral speech, which embodies an internal dynamism that encourages thinking and real discussion. In this way, students obtain the opportunity to receive pre-existing knowledge, which they must accept as an occasion for criticism in order to overcome what is given, to see beyond the obvious and to form their own cognitive and why not innovative proposal.

It is obvious that the immediate contact that is developed between tutors and students in conventional and traditional institutions ensures their dynamic interaction and facilitates the process of instructing theoretical, artistic and philosophical concepts and courses (Simonson, Smaldino, Albright \& Zvacek, 2008). On the other hand, the case is different in distance learning-programs where the instructor must approach and understand the student without any personal contact (Alexander, 2001). That makes it difficult for the instructor to create his own image for the needs and the background of his students in order to adapt his tuition and build up the appropriate conditions to ensure socialization of the group, interaction and dialogue (Guri-Rosenblit, 2005; Keegan, 2001).

Furthermore, distance learning is based on a media or medium (Holmberg, 2003). Therefore, the role of modern technology appears to be rather crucial in the learning process since only through it the necessary premises and bonds could be developed (Carswell, Thomas, Petre, Price \& Richards, 1999). In that frame, the most basic method of teaching used in distance education is written texts, which are delivered to students through printed material, books, Compact Discs, e-mail or Internet pages. Secondly, a large scale of applications in distance learning concern sound and image technologies that have to do not only with the communication of knowledge (for example telephone conversations, video and sound recordings, power-point presentations, computer programmed exercises or radio broadcasts) but also with the development of interpersonal relations between everyone involved in the process (sound or video conference). The latter applications presuppose the use of Internet, a technology that is convenient, cheap, world-spread and accessible by anyone regardless geographical or temporal boundaries. At the same time, while most methods do not provoke the parallel activity of instructors and students (asynchronous distance education), both sound and videoconference presuppose that everyone participates in the educational process at the same time (synchronous distance education), creating in this way a different kind of face-to-face communication that provides possibilities for direct contact, dialogue and multiple ways trafficking of information (Simonson et al., 2008).

\section{Conclusion}

Having all the above in mind, the critical question that we posed earlier about the way Art courses should be instructed seems to find an answer that is connected with the proper and necessary method, which distance education institutions should adopt and cultivate in order to achieve the necessary level of interaction and social dialogue among students and tutors. It is apparent that teaching Art "demands" synchronous distance education depended on oral communication provided from sound and 
videoconference sessions, whose obvious and frequent existence in the academic programs should not be just an option, but an "obligatory" premise. However, this does not mean that all other practices of distance education lose their value. On the contrary, they consist an extremely useful framework for the student so as to further evolve certain intrinsic skills and self-learning abilities. With that background nonetheless, tutors and students of Art would have the opportunity to exploit for their own good the accomplishments of new technologies, getting ready to enter through them the world of oral dialogue, intense criticism and live interaction that will ameliorate their qualities and will reveal to them a new spiritual and intellectual academic reality.

Additionally, we must never forget that every educational process exists for the benefit of the student, since the student is the center of education. Therefore, in every field, higher institutions ought to offer not only a complete context of relevant knowledge but also a methodological thought to access and approach that knowledge. In the case of Art instructed through distance learning, the student should not be left to explore the secrets of the Art-world all alone, having as support only written texts or soulless presentations and assignments. If this happens, then the acquisition of knowledge will lose its scientific character and the cognitive level that the student may reach will be downgraded to that of empirical craftsmanship. Thus, it is crucial to insist in underlying the philosophical substance of everything that is artistic, a fact that will guide correctly the effort to understand the phenomenon of Art and to transmit it didactically with the proper methods surpassing every geographical or temporal obstacle.

\section{References}

Alexander, S. (2001). E-learning Developments and Experiences. Education \& Training, 43 (4/5), 240248.

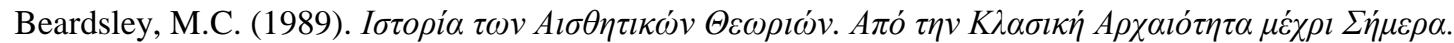

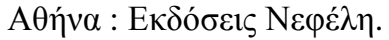

Boas, G. (1964). The Arts in the Encyclopedie. The Journal of Aesthetics and Art Criticism, 23 (1), $97-$ 107.

Carswell, L., Thomas, P., Petre, M., Price, B. \& Richards, M. (1999). Understanding the Electronic Student: Analysis of Functional Requirements for Distributed Education. Journal of Asynchronous Learning Networks, 3 (1), 7-18.

Collingwood, R.G. (1974). The Principles of Art. London, Oxford, New York: Oxford University Press.

Danto, A. (1974). The Transfiguration of the Commonplace. The Journal of Aesthetics and Art Criticism, 32 (2), 39-148.

Danto, A. (1998). Beyond the Brillo Box: The Visual Arts in post-historical perspective. Berkeley: University of California Press.

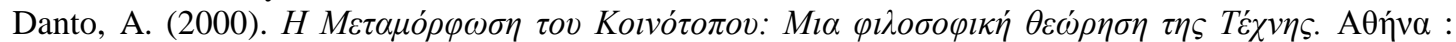

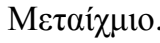

Danto, A. (2001). The Madonna of the Future: Essays in a pluralistic art world. Berkeley: University of California Press.

Guri-Rosenblit, S. (2005). Distance Education and E-learning: Not the Same Thing. Higher Education, 49 (4), 467-493.

Holmberg, B. (2003). Distance Education in Essence. An overview of Theory and Practice in the Early Twenty First Century. Oldenburg : Bibliotheks- und Informationssystem der Carl von Ossietzky Universität Oldenburg (BIS) - Verlag.

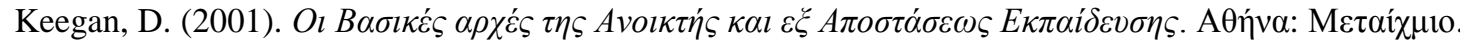
Kemal, S. (1986). Kant and Fine Art. An Essay on Kant and the Philosophy of Fine Art and Culture. Oxford : Clarendon Press.

Kristeller, P.O. (1951). The Modern System of Arts: A Study in the History of Aesthetics Part I. Journal of the History of Ideas, 12 (4), 496-527.

Munro, T. (1954). Les Arts et leurs Relations Mutuelles. Paris: Presses Universitaires de France. 
Nichols, G. A. (1877). Art Education Applied to Industry. New York: Harper \& Brothers Publishers.

Pollitt, J.J. (1974). The Ancient View of Greek Art: Criticism, History and Terminology. New Haven, London : Yale University Press.

Simonson, M., Smaldino, S., Albright, M. \& Zvacek, S. (2008). Teaching and Learning at a Distance. Foundations of Distance Education. New Jersey: Prentice Hall Higher Education.

Souriau, E. (1969). La Correspondance des Arts. Eléments d' Esthétique compare. Paris: Flammarion.

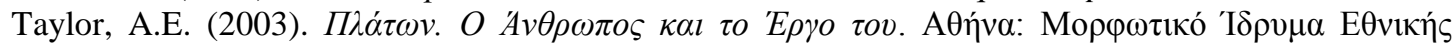

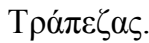

Tatarkiewicz, W. (1963). Classification of Arts in Antiquity. Journal of the History of Ideas, 24 (2), 231-240.

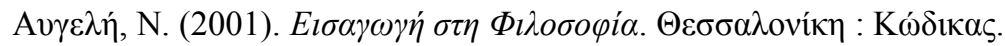

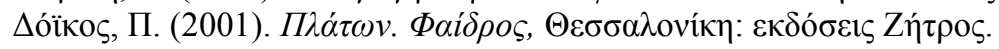

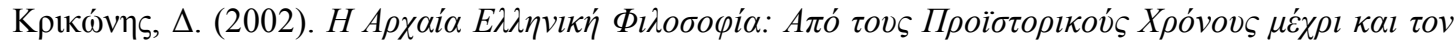

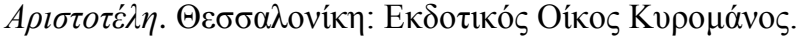

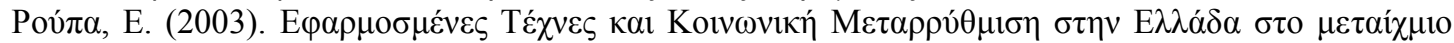

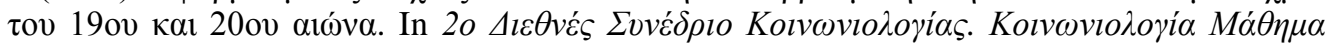

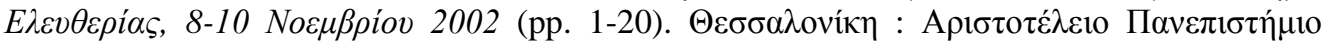

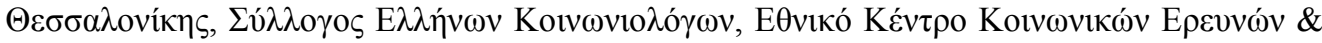
International Sociological Association. 